\title{
PHASES IN THE METAMORPHISM OF THE SCHISTS OF SOUTHERN BERKSHIRE*
}

\author{
BY WILLIAM H. HOBBS
}

(Read before the Society August 16, 1892)

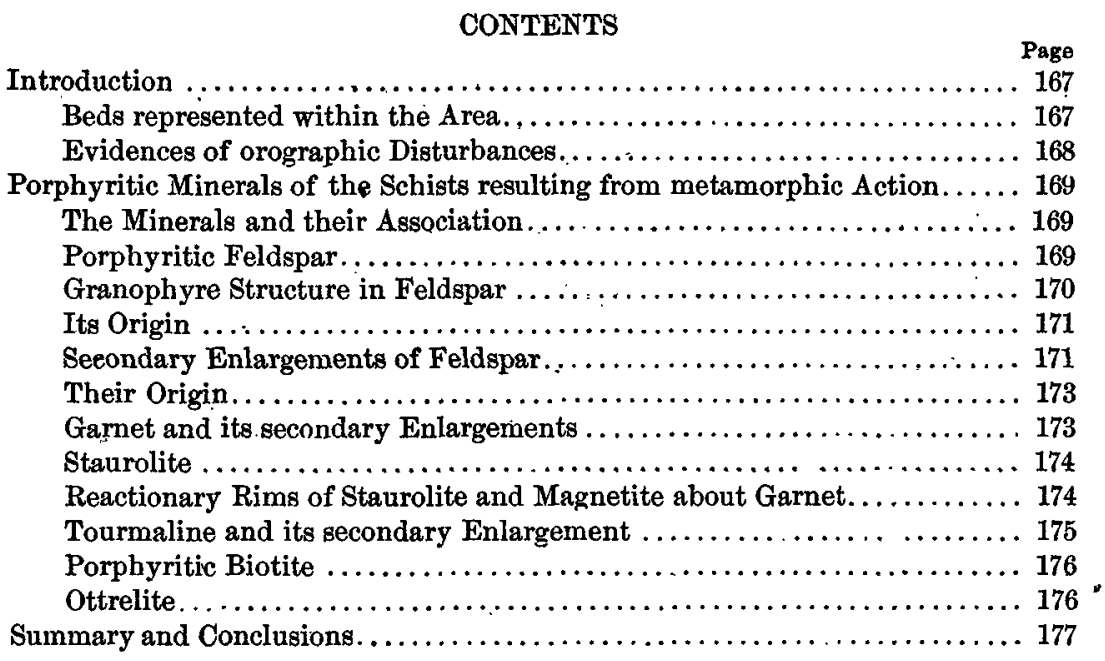

\section{INTRODUCTION.}

Beds represented within the Area.-In southwestern Berkshire county, Massachusetts, and in northwestern Litchfield county, Connecticut, is an area in which non-calcareous schistose rocks alternate with limestones which are in part micaceous, dolomitic, graphitic, pyroxenic, tremolitic or quartzitic. $\dagger$ Though the schists are the "mountain rock," they are found in the valleys as well and are frequently inclosed as islands in

\footnotetext{
* Published with the permission of the Director of the United States Geological Survey. t The area has been described and mapped by Professor J. D. Dana : On Taconic Rocks and Stratigraphy, with a Geological Map of the Taconie Region. Am. Jour. Sei., Jd ser., vol. xxix, pp. 205222, pp. 437-443, pl. ii.
} 
the limestone. The rocks here described occur in portions of the townships of Egremont, Sheffield and Mount Washington, in Massachusetts, and of Canaan and Salisbury, in Connecticut. They have been studied areally and structurally in the field and petrographically in the laboratory. The full report of the investigation will appear elsewhere.*

The area includes three beds of schist separated by beds of limestone, besides the thin layers of the former which are sometimes found within the limestones near the contact. The lowest of these schist beds is associated with quartzite and gneiss, and is more lacking in uniformity of character than the others. It incloses numerous veins of coarse pegmatite and is specially rich in tourmaline, though this mineral is also found in the two other horizons.

The next younger schist is separated from the one just mentioned by a dolomite, which is always very crystalline, and at many localities contains white pyroxene, tremolite or phlogopite. It moreover contains layers of graphitic rock and of canaanite. ${ }^{\prime}$ The schist horizon itself is quite variable in character, but is frequently distinguished by the occurrence of macroscopic garnets and staurolite.

The upper schist bed is separated from the last mentioned by a limestone in which neither sahlite, tremolite nor canaanite has been found. The schist itself is free from the macroscopic garnets and staurolite characteristic of the central bed. In common with both the other beds, it contains porphyritic crystals of feldspar, but here they seem more generally to have glistening cleavage surfaces: Especially in the Mount Washington area this bed shows facies that are quite sericitic or chloritic, the latter with magnetite often in octahedra as big as a pea. Ottre- lite, though not restricted to this horizon, is more frequently found here than in either of the others. Though the rocks of the three non-calcareous beds have a preponderance of feldspar, they are structurally schists and they are so designated, as it is convenient to distinguish them from typical gneisses in adjacent territory. Notwithstanding characteristic differences can be pointed out, serving to distinguish the three beds when regarded as units, individual hand specimens from each often show resemblances more striking, so that it is generally impossible to refer a specimen to a definite bed on the basis of petrographic character only.

Evidences of orographic Disturbances. - Typically metamorphic minerals abound in all beds, but especially in the central schist bed and the dolomite underlying it. The beds have been thrown into sharp folds, most frequently reversed, with resulting shear planes and secondary foliation at many localities.

\footnotetext{
* The work here referred to forms part of an investigation conducted by Professor Raphael Pumpelly for the United States Geological Survey.

† American Geologist, rol. xv, 1892, p. 45.
} 


\section{Porphyritid Minerals of the Schists resulting from metamorphic Action.}

The Minerals and their Association.-It is my object in this paper especially to describe the so-called porphyritic constituents of the schists that have been developed or modified by metamorphic agencies. Under this head are included feldspar (largely an acid plagioclase), garnet, staurolite, tourmaline, biotite and ottrelite. Other constituents present in greater or less quantity are sericite, quartz, graphite, chlorite, magnetite, ilmenite, pyrite, fibrolite, calcite, rutile, sphene (and leucoxene), zircon and apatite. In nearly all specimens there is a matrix made up of varying amounts of feldspar, quartz and a micaceous mineral, which is in some cases a silvery mica (sericite); in other instances sericite with biotite or chlorite. Associated with these minerals are accessory graphite, ore material, etc. Almost without exception porphyritic feldspars occur in the matrix, usually many times larger than the feldspar grains composing it.* In addition to the modifications of the rock arising from the micaceous constituents present, petrographic variations consist mainly in the character of the porphyritic feldspar and in the presence or absence of the other porphyritic constituents, viz: garnet, staurolite, tourmaline, biotite and ottrelite. The central schist bed has furnished most of the specimens in which the structures I shall describe were observed, though such structures do not seem in all cases to be restricted to that bed.

Porphyritic Feldspar.-The porphyritic feldspars appear under a number of modifications. In certain facies of the rock they are more or less oval in shape and inclose with more or less uniformity blades of sericite, particles of graphite, ore material or tourmaline. They are commonly either simple individuals or simple twins. They quite resemble in sections the beautiful photomicrograph which is figure 8 of the paper by Wolff on "The Metamorphism of Clastic Feldspar in Conglomerate Schist." $\dagger$ Though these feldspars may show no marked evidences of strain, many instances of polysynthetic twinning have been observed, and the occasional localization of the lamellæ about cracks in the individual would indicate that the twinning is the result of internal mechanical movement. The twin lamellæ allow of the determination of the feldspar as an acid plagioclase.

Dynamic metamorphism has at other localities been more intense, as evidenced in sections where the granulation of the feldspars may be

* See descriptions of similar feldspars in the sehistose and conglomeratic rocks of Hoosac mountain and elsewhere. (Pumpelly: The Relation of Secular Rock-Disintegration to Certain Transitional Crystalline Schists. Bull. Geol. Soc. Am., vol. ii, 1891, pp 209-224. Wolff: Metamorphism of Clastic Feldspar in Conglomerate Schist. Bull. Mus. Comp. Zool., vol. xyi, 1891, pp. 173-183, pls. i-1i.) $\dagger$ Bull. Mas. Comp. Zool, vol. xvi, 1891, pp. 173-183, pls. i-ii. 
seen. This may be largely peripheral, as in a specimen (number 3230 )* from near Ore Hill, or it may include nearly the entire crystal, as in a number of thin sections (number 3224) from Miles mountain. Such pronounced granulation seems, however, to be most developed in the vicinity of shear planes, and is accompanied by a stretching and tearing of the other constituents. Figure $1, A$ shows the effect of this action on two adjacent garnets (number 3230 ).

Granophyre Structure in Feldspar.-Those structures which I desire here more especially to emphasize; however, seem to be found farther removed from shear planes, and concern phases of metamorphism where mechanical movement has been a minimum. In such localities the feldspars have frequently a mottled appearance, like $D$ in figure 1 (numbers 3111 , $3326,3328,3463)$.
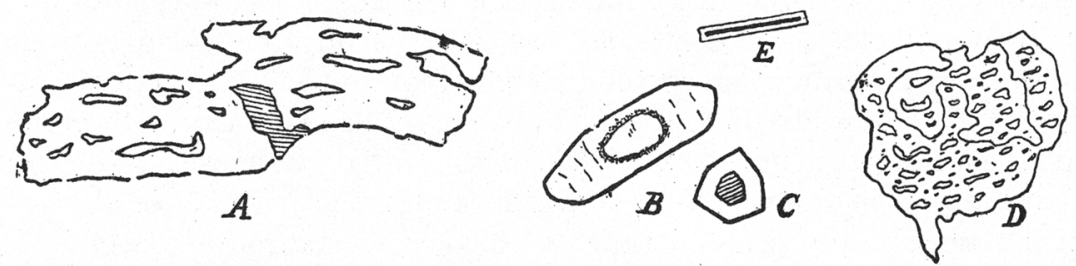

Frgure 1.-Examples of Deformation and modified Growths of Minerals in Schists.

$A=$ stretched garnets. $B=$ secondary growth of tourmaline; the oval core has brown tones, the enlargement blue or plum tones; the cloudy material near the junction is probably graphite. $C=$ zonal structure in tourmaline. $D=$ mottled feldspar. $E=$ parallel growth of ilmenite and chlorite.

The included areas sometimes take the form of curving canals, at others polygonal outlines, and, in short, exhibit all the peculiarities of the micropegmatite or granophyre structure. Hexagonal outlines characterize many of the areas, and there can be little doubt that they are in these cases quartz (number 3463).

The inclosed quartz extinguishes alike over considerable areas, but sometimes shows several orientations within a single crystal of feldspar. $\dagger$ The feldspars which show this structure exhibit in many cases the minimum of crushing and but little effect of stress, while in other cases the granophyre structure coëxists with a pronounced granulation and exhibition of secondary twinning. In the latter case the structure is very complicated, and it is difficult to distinguish the secondary quartz from the mosaic of feldspar. It was frequently observed (in those cases where but little deformation could be made out) that the granophyre occupies the center of a crystal, leaving a clear rim.

* The numbers of sections are those of the United States Geological Survey collection.

†Cf. Iddings, Obsidian Cliff, Yellowstone National Park: Seventh Ann. Rep. U. S. Geol. Sur., 1888, p. 275 , plate $\mathrm{xv}$, fig. 5 . 
Its Origin.-The question of the origin of the granophyre in these doubtless clastic rocks is a difficult one. It is a question that deserves further study, and I hope later to be able to throw a little more light on the problem. For the present it can be said that the relation of the intergrown quartz to the quartz outside, as exhibited in a number of sections, lends no support to the view that the granophyre structure has been preserved from some detrital grains which have an igneous origin, but that it is of a secondary nature, being developed in the already formed rock. -The usual interpretation of granophyre structure to indicate an igneous origin for the rock in which it occurs is no longer tenable. Irving in 1883* described micropegmatite in a number of granitic porphyries and augite syenites from Lake Superior, the secondary nature of which was evident from its quartz being oriented like the areas of secondary quartz lying without the feldspars. Somewhat similar cases have been described by Judd. $\dagger$ In a recent memoir by Julius Romberg $\ddagger$ on the petrographic characters of an extensive series of Argentine granites the granophyric structures are described in much detail with the aid of beautiful plates. The author raises the question of their secondary origin through weathering, and adduces many facts which make it probable that this is their origin.

In some of the feldspars which show the mottled structure in the rocks now under consideration it can be determined that the inclosed areas are feldspar of a somewhat different composition (microperthite structure). This is particularly well shown in the instance of a feldspar core having a rim which polarizes yellow, the core polarizing gray. A set of mottlings in the core give the same yellow tint as the rim and extinguish with it. This would seem to show that the original feldspar core had been partially replaced by a feldspar of different composition, which composes the rim entire. This view is quite in harmony with Wolff's deductions concerning the feldspars in the conglomerate schist of Hoosac mountain.|l

Secondary Enlargements of Feldspar.-Secondary enlargements of feldspar seem to be quite common in the rocks under investigation, and they have been found at localities widely separated.§ Occasionally these en-

\footnotetext{
*The Copper-bearing Rocks of Lake Superior: Monograph V, U. S. Geol. Survey, 1883, p. 114, plates xir, xr.

+ On the Growth of Crystals in Igneous Rocks after their Consolidation: Quart. Journ. Geol. Soc. vol. xlv, 1889, po. 175-186. pl. vii. Ibid., vol. xlii, 1886, p. 72.

† Romberg. Petrogruphische Untersuchungen an argentinischen Graniten, mit besonderer Berücksichtigung ihrer Structur und der Entstehung derselben: Neues Jahrbuch f. Mineralogie, etc., Beilage-Band viii, 1892, pp. 314-323, 374-378, plates ix-xii.

\| Loc. cit. See also Lehmann, Jahresbericht der Schlesischen Gesellschaft für Vaterländische Cultur, 1886, pp. 119-120.

3. Thorpe mountain (numbers 3574, 3476 ana 3477); northeastern slope of Mount Washington, (number 2129); southeastern slope of Mount Washington (number 3104); Miles mountain (number 3213 ), and near Raltlesnake hill (number 3030).
} 


\section{W. H. HOBBS-METAMORPHISM OF BERKSHIRE SCHISTS.}

largements are visible under a lens, owing to the unequal distribution of graphite (number 3574). The commonest case of enlargement is that in which there is but one secondary growth visible (figure $2, B, C, D$ ). The original growth shows crystal boundaries and is sharply outlined against the enlargement, which has generally an irregular boundary and contains more sericite, interpositions of ore, etc. The enlargement is generally at least of a more basic feldspar than the core, as shown by the extinction angles. In the growths figured, $B$ is evidently cut near the brachypinacoid and $C$ probably near the base, as in this latter instance the extinction angles are nearly the same and closely parallel to the long side. It is thus probable that both feldspars are intermediate in composition between oligoclase and andesine. In $D$ is represented an unusual growth, of which the core is simply twinned, though the enlargement is not (see plate 3 , figure $2, A$ ). In the same section is another growth in which core and rim are twinned alike. I have noticed some-

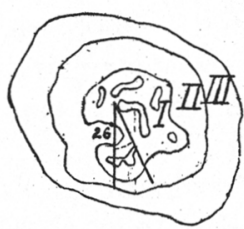

A

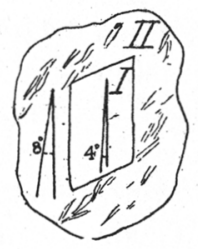

$B$

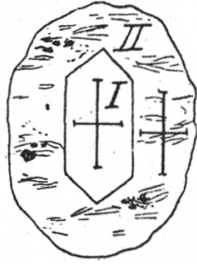

C

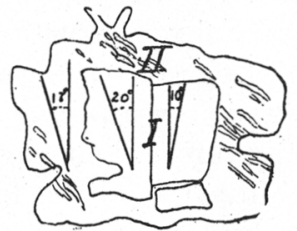

$D$

Figure 2.-Secondary Enlargements of Plagioclase.

$A, B, C$ and $D$ are examples of secondary enlargements of plagioclase which occur in the schist of Mount Washington, near Joyceville (number 3104). I is the core in each case; II and III are the enlargements. $A=$ rounded mottled core with two enlargements ; $B C=$ examples of core with crystal boundaries; $D=$ unusual instance of twinned core surrounded by an untwinned enlargement.

what analogous cases in the growths of epidote around allanite from the porphyritic granite of Ilchester, Maryland,* the core of allanite being twinned, though the encircling oriented epidote is a single individual. In the gneiss of Warner mountain, east of Sheffield, Massachusetts, such growths occur, and here the epidote has been observed twinned like the allanite in one instance, and in another the allanite core is twinned and the epidote untwinned. Van Hise $†$ has figured a grain of feldspar with an enlargement, and both are twinned alike. Wolff states that in the enlarged feldspars of the conglomerate schists of Huosac and Bear mountains, twins are sometimes common to both core and rim, but also are found only in the core.\$ Judd $\|$ describes and figureș an enlargement of

* Am. Journ. Sci., 3d ser., vol. xxxviii. 1889, pp. 223-228, figs. 1 and 2.

† Bull. no. 8, U. S. Geol. Survey, pt. ii ; also Am. Journ. Sci. 3d ser., vol. xxvii, 1884, p. 399.

† Loc. cit., p. 182.

|| Quart. Journ. Geol. Soc., xlv, p. 186, pl. vii, figs. 1 and 2. 
feldspar in the "labradorite andesite" of the isle of Mull, in which the twins of the core are prolonged as twins in a more acid feldspar.

An enlargement where the core is unmottled but has a rounded outline is seen at $A$ of figure 1 , plate 1 . In figure $2, A$, there is exhibited a somewhat different modification. In this instance, as in some others, the core is mottled and of irregular outline. Two enlargements are indicated by the different extinction angles (Cf. also plate 1 , figure $1, B$ ). Second enlargements have been found also at other localities (numbers $3213 \frac{1}{2}$ and 3115). In a specimen from near Jug End, Mount Washington (number 3139) there seem to be several zones of growth in feldspar.*

Their Origin.-The fact that the cores of many of the growths which have been described have crystal boundaries makes it extremely improbable that they can be of detrital origin, though the rocks themselves are undoubtedly clastic. The most probable view of their origin, it seems to me, would regard them as a metamorphic product due to the recrystallization of the detrital grains of the rock, as in the better-known cases of garnet and staurolite. $\dagger$

Garnet and its secondary Enlargements.-As already stated, this mineral when in macroscopic crystals is specially characteristic of the central schist bed. It is the common dark red, nearly opaque variety, and occurs in rhombic dodecahedra with truncations by the icosatetrahedron. The crystals vary in size from those that are microscopic to those, a centimeter or two in diameter. Frequently, though not always, they are associated with staurolite. They exhibit the usual characters on microscopic examination. They have a decided pink absorption and are sometimes compact, though often ragged in appearance from the inclosure of the constituents of the matrix. Minute hair-like interpositions, which are very abundant, are with much probability rutile. In the schist of Johnny's mountain, near Sheffield (number 3114) interesting secondary enlargements of the garnet have been observed. The core or first growth is pink and comparatively free from inclusions, with the exception of the hair-like interpositions above referred to. The rim of secondary enlargement, making from one-half to two-thirds the area of the entire growth, is nearly colorless, and near its junction with the core is filled with an aggregation of cloudy ore material, probably magnetite. Where several crystals have formed in a continuous aggregate, the enlargement incloses the aggregate, just as in other cases it incloses an individual (figure $3, A$ ).

\footnotetext{
*Cf. Judd, loc. cit., plate vii, fig. 3 .

$\dagger$ For the literature of secondary feldspar enlargements in rocks of eruptive origin see :-

Haworth, A Contribution to the Archean Geology of Missouri; Inalug. Dissertation, Johns Hop-

kins University; also printed in American Geologist, May and June, 1888.

Judd. Quart. Journ. Geol. Soc.. xlv, 1889, pp. 175-186.

Romberg, Neues Jahrbuch für Mineralogie, etc., Beilage-Band viii, 189?, p. 304, plate xv, fig. 54 .
} 


\section{W. H. HOBBS-METAMORPHISM OF BERKSHIRE SCHISTS.}

In one instance stains of iron oxide were observed to traverse the enlargement and stop abruptly at its junctions with the core (figure $3, B$ ).

Staurolite.-This mineral has only been found in the central schist bed. It is usually macroscopic and its crystals sometimes attain to a length of two or three centimeters. They are bounded by the usual forms, and are frequently twinned in inclined crosses. The color is usually black, but is sometimes cinnamon-brown. Under the microscope the mineral presents the usual characters with strong pleochroism. Like the garnet, it is sometimes compact, sometimes very ragged, from inclosures of the matrix. Secondary enlargements have not been determined, but the observation of crystals with an outer zone which, unlike the center, is free from inclusions, makes their occurrence not improbable.
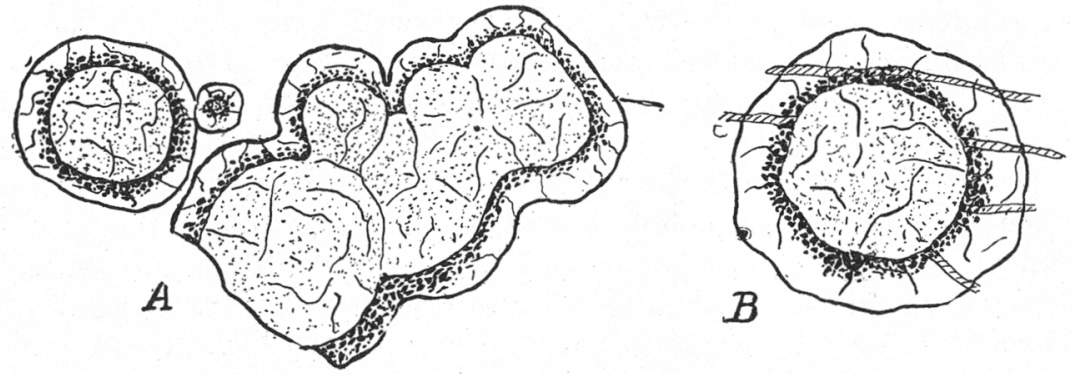

Figure 3.-Garnets with secondary Enlargements.

From schist of Johnny's mountain, near Sheffield.

Reactionary Rims of Staurolite and Magnetite about Garnet.-The arrangement of staurolite and garnet is in some instances such as to show that the staurolite is a later development. Its crystals seem sometimes to be developed about and near garnets, as in the rock from the Lion's Head, northwest of Salisbury (number 3431). In the schists of the north end of the ridge called June mountain (northeast of Sheffield village), a crown of staurolite prisms almost encircles an individual of garnet (number $3306 \mathrm{~B}$ ). The garnet is pink, and is filled with microlites (rutile). Between the encircling crown of roughly radial staurolite crystals and the garnet individual is considerable magnetite (see figure 4). The fact that staurolite has not been found except with garnet, though garnet is found unaccompanied by staurolite, taken in connection with the statements just made, shows that staurolite has generally been a later development in the rock, and probably requires more intense metamorphism. In some instances, at least, it is indebted to the garnet for its iron and probably also much of its alumina and silica. In the case of the crown about garnet, we seem to have a true reactionary rim, where the iron of 
the garnet has been sufficient to supply the staurolite and leave a residue, which appears as magnetite.

Tourmaline and its secondary Enlargement.-This mineral is specially abundant in the lowest schist bed, occurs usually in black prisms, and in size varies from microscopic dimensions to several centimeters. In the pegmatite veins it is often found in knots as large as one's fist, inclosed in quartz. It is less abundant in both the other horizons, but appears not infrequently in crystals, which are just discernible under the lens. Under the microscope the only noteworthy characters of this tourmaline are the absorption and a marked zonal structure without per-

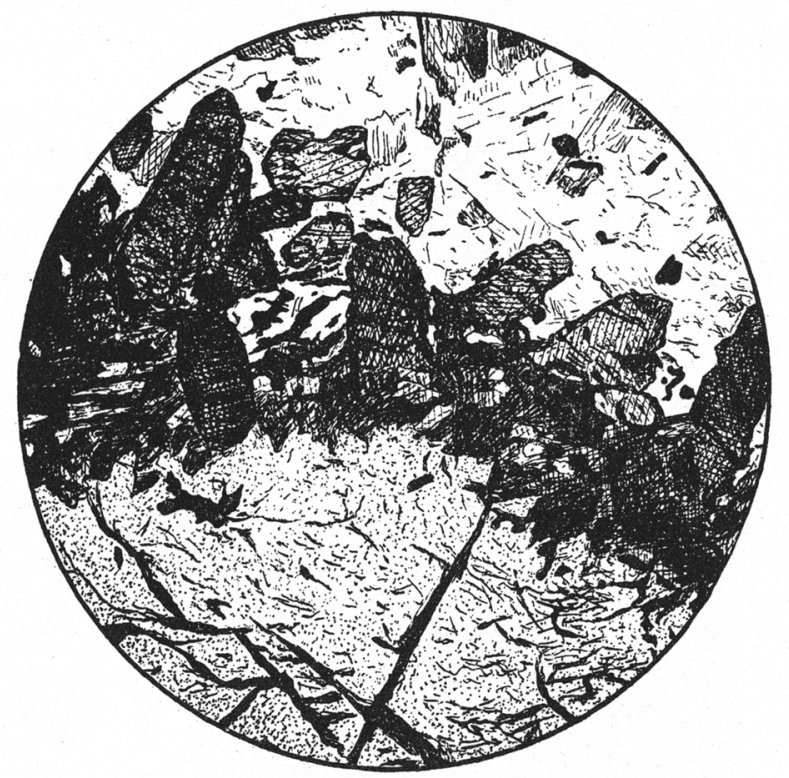

FIGURE 4.-Portion of a Crown of Staurolite and Magnetite encircling a garnet Individual.

In ordinary light. $\times 33$.

ceptible gradations in color. There are nearly always a core and an encircling rim. The core has usually pleochroism in blue to plum tones, whereas the rim shows brown tones like biotite. Sometimes the outline of the core is parallel to the bounding planes (figure 1, $C$ ). In the graphitic mica schist of the second railroad cut west of Ore Hill (number 3534) undeniable enlargements of tourmaline are found. One of these is represented in figure $1, B$. The core is oval, and is surrounded by a halo of cloudy opaque material (graphite). It shows the brown tones like biotite. About this rounded and probably detrital core a stoutly colum- 
nar crystal of tourmaline has been formed and oriented like the core. The dichroism of the enlargement is unlike the core, as it shows plum tones approaching purple. Secondary enlargements of tourmaline have been observed simultaneously by Whittle in the Green mountains and are described elsewhere* in this volume.

Porphyritic Biotite.-This mineral quite frequently appears in porphyritic blades, generally across the lamination. These are sometimes several millimeters in diameter, and in the rock in which they occur are several times larger than the sericite and biotite of the matrix. Small sericite blades are generally inclosed in this porphyritic biotite.

Ottrelite.-Ottrelite is found in the Mount Washington area, where its minute disks occasionally spangle the surface of the schist. Under the microscope the basal sections appear irregular and somewhat opaque. Prismatic sections are lath-shaped and are sometimes broken across. They show twins both simple and polysynthetic according to the Tschermak law. The index of refraction is higher than that of chlorite, and extinction angles were measured as high as $\mathbf{1 7}$ degrees. The absorption is in blue, green and yellow tones. The double refraction is feeble, causing low gray interference colors. It is often difficult to distinguish this mineral from chlorite, which generally accompanies it. Growths of ilmenite similar to those described by. Wolff in the New England schists $\dagger$ are not uncommon, but they are here apparently of chlorite, possibly an alteration product of ottrelite. Whittle $\ddagger$ has shown that the ottrelite in rocks from the Green mountains is altered extensively to chlorite. The development of ottrelite in the Salmien superieur has been made the subject of an extended memoir by Prof. J. Gosselet,\| of Lille. This memoir is important because it throws a great deal of light on the mode of development of other porphyritic constituents of metamorphic schists. M. Gosselet concludes (p. 202) that the ottrelite was formed after the rock was in the condition of a schist or phyllite, since all the constituents of the schist are included in it. Further, the vicinity of the ottrelite crystals shows an impoverishment of quartz. There has also been a local movement of the particles around the ottrelite crystals at the time of their development. The larger grains of hematite and ilmenite have been forced out from the positions occupied by the ottrelite and concentrated in a zone around it. The diversion of the trains of inclusions in the rock as they enter the ottrelite crystal, and the bending of mica scales,

*Ante, p. 152.

tOn some Occurrences of Ottrelite and Ilmenite Schist in New England : Bull. Mus. Comp. Zool., vol, xvi, 1890, pp. 159-165.

fAn Ottrelite-bearing Phase of a Metamorphic Conglomerate in the Green Mountains : Am. Jour. Sei., 3d ser., vol. xliv, 1892, pp. 274-275.

I Etudes sur l'origine de l'Ottrelite, 1re Étude, l'Ottrelite dans le Salmien superieur: Ann. Soc. Geol. Nord; Lille, vol, xv, 1888, pp, 185-318. 
show that a general movement occurred in the rock subsequent to the formation of the ottrelite, tending to bring the ottrelite crystals parallel to the schistosity. Professor Gosselet ascribes the development of the ottrelite to heat, of which the cause is unknown.* The spaces left behind the mineral by its movement become filled either at the time or subsequently by muscovite, quartz and oxide of iron, giving rise to peculiar tufts going out from the mineral. Besides the crystals of ottrelite, M. Gosselet describes with great care in the same rocks somewhat irregular rounded areas (noyaux) of cloudy, in part doubly refracting, material, surrounded by one or more zones, differing in some respects from the core, which he believes to be the remains of more elementary forms of ottrelite rather than crystals-globulites.

\section{Summary AND Conchustons.}

From the foregoing, it may be asserted with much probability that the minerals of a porphyritic nature which occur in the schists, viz., feldspar, garnet, staurolite, tourmaline, biotite and ottrelite, were developed in originally clastic rocks as a result of the orographic disturbances to which they have been subjected. Internal mechanical movement seems to have played only a subordinate rôle in their formation, as shearing brings about a crushing and tearing of the constituents not generally observable in the sections. The development of the porphyritic constituents seems therefore to be due to a partial recrystallization of the rock as a result of what I would call static metamorphism-i. e., metamorphism in which pressure is the important factor, in contrast to internal movement, though heat and a mineralizer were important adjuncts. The universal distribution of the porphyritic feldspars might indicate that they require a less intense metamorphism for their development than do garnet and staurolite, and this is probably true, though it cannot be asserted that some of these feldspars are not detrital grains like a portion of those described by Wolff. $\dagger$ Evidence has been given to show that the garnet developed largely before the staurolite, and that the latter probably requires for its formation more intense metamorphic action. The staurolite orystals have been developed, at some expense to the garnet, for iron, and probably also alumina and silica. This is shown by the crown of staurolite crystals about garnet in the June mountain schist. This fact, taken in connection with the secondary enlargements of feldspar, garnet, and tourmaline, and the probability of enlargements in the case of staurolite, indicates that the metamorphism which these schists have suffered

\footnotetext{
* "La formation de l'ottrelite est da a une production de chaleur dont il faudra chercher la cause." Loc. cit., p. 203.

† Bull. Mus, Comp. Zool, vol, xvi, 1891, p. $17 \mathbf{5}$.
} 
was not a continuous process, but occurred in stages, of which there must have been several. It was in one of the later of these stages that the staurolite was developed.

The importance of the enlargement of mineral fragments in clastic rocks as a factor in their alteration by metamorphism, has been emphasized by Irving and Van Hise in their papers on the rocks of the Lake Superior region. This study presents a somewhat different phase of the subject and adds an instance of their occurrence in rocks which have been more profoundly metamorphosed. The investigation here outlined is not eompleted. The interesting problems of the chémical nature of the reactions involved in the development of the feldspars and their secondary enlargements, and of the other porphyritic constituents, will require for its solution a separation and chemical examination of the different constituents.

In conclusion, I would acknowledge my indebtedness to Dr G. H. Williams and Dr J. E. Wolff for valuable suggestions and criticism.

\section{Explanation of Plate.}

Sections of garnetiferous porphyritic Schist from the southeast Slope of Mount Washington, showing secondary Growths of Feldspar.

Locality (number 3104) on road between Joyceville and Plantain Pond.

Frgure 1.-A = Secondary growth of feldspar, of which the core has a rounded outline.

B = Feldspar growth with two distinct enlargements indicated by different extinction angles. The core has a micropegmatite structure. Crossed nicols. $\times 77$.

Figdre 2.-A = Simply twinned feldspar core with an untwinned enlargement. Crossed nicols. $\times 48$. 
Downloaded from gsabulletin.gsapubs.org on August 10, 2015

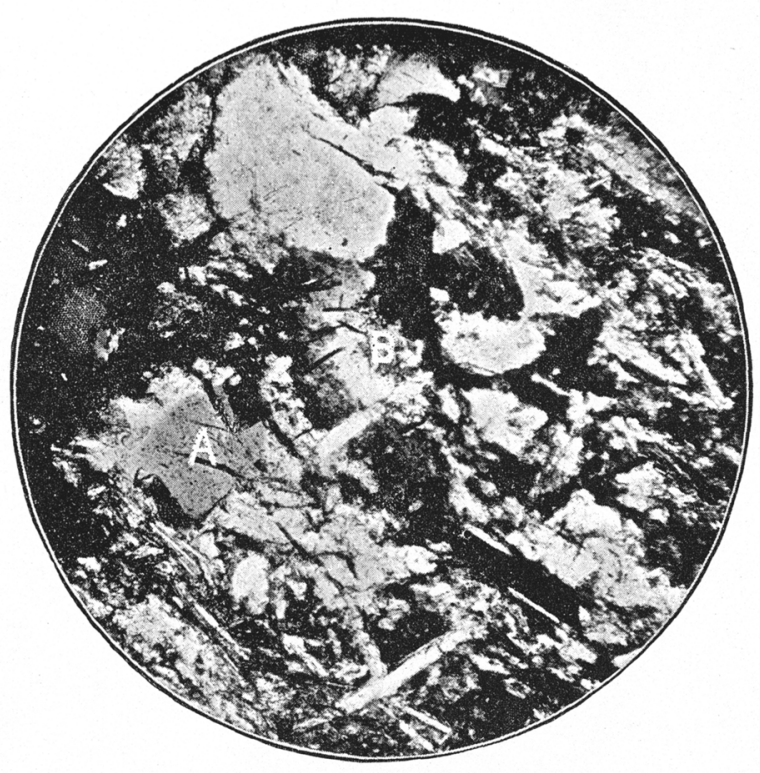

Figure 1

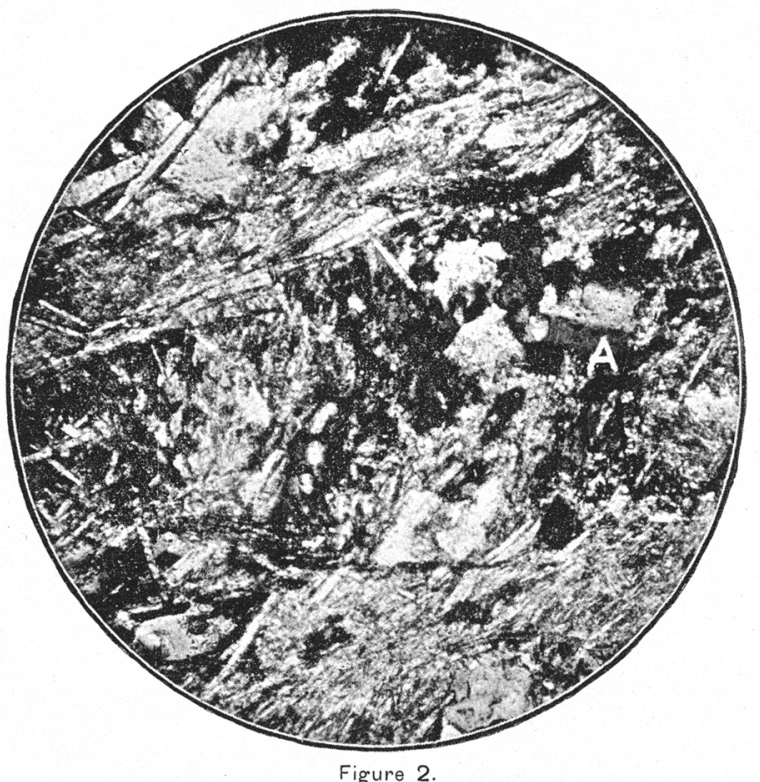

Figure 2.

SECTIONS OF GARNETIFEROUS PORPHYRITIC SCHIST. 
Downloaded from gsabulletin.gsapubs.org on August 10, 2015 


\title{
Geological Society of America Bulletin
}

\section{Phases in the Metamorphism of the Schists of southern Berkshire}

\author{
William H. Hobbs
}

Geological Society of America Bulletin 1892;4, no. 1;167-178 doi: 10.1130/GSAB-4-167

Email alerting services

Subscribe

\section{Permission request}

click www.gsapubs.org/cgi/alerts to receive free e-mail alerts when new articles cite this article

click www.gsapubs.org/subscriptions/ to subscribe to Geological Society of America Bulletin

click

http://www.geosociety.org/pubs/c opyrt.htm\#gsa to contact GSA

Copyright not claimed on content prepared wholly by U.S. government employees within scope of their employment. Individual scientists are hereby granted permission, without fees or further requests to GSA, to use a single figure, a single table, and/or a brief paragraph of text in subsequent works and to make unlimited copies of items in GSA's journals for noncommercial use in classrooms to further education and science. This file may not be posted to any Web site, but authors may post the abstracts only of their articles on their own or their organization's Web site providing the posting includes a reference to the article's full citation. GSA provides this and other forums for the presentation of diverse opinions and positions by scientists worldwide, regardless of their race, citizenship, gender, religion, or political viewpoint. Opinions presented in this publication do not reflect official positions of the Society.

(C) 1892 Geological Society of America

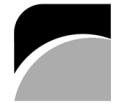

THE GEOLOGICAL SOCIETY OF AMERICA 
Downloaded from gsabulletin.gsapubs.org on August 10, 2015

\section{Notes}

(C) 1892 Geological Society of America

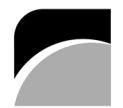

THE

GEOLOGICAL SOCIETY

OF AMERICA 